\title{
Public Transport Crowding Valuation: Evidence from College Students in Guangzhou
}

\author{
Jianrong Liu and Huiying Wen
}

South China University of Technology

\begin{abstract}
Overcrowding has grown to be an increasingly important issue for public transit in Guangzhou, China. To capture traveler benefits of reduced crowding from improved public transport, it is necessary to identify the relevant importance of crowding to travelers. This paper analyzes the disutility of crowding in metro car and bus transit with discrete choice models. Based on the stated preference survey data from college students in Guangzhou, the results show that there is non-negligible impact of crowding on passenger travel. The relationship between the disutility of crowding and standee density is not linear; that is, the disutility increases at a modest rate as the standee density increases when it is easy to move around in cars and increases rapidly when it is difficult to move around in cars. Also, there is only a slight difference between the effects of crowding on metro and bus transit.
\end{abstract}

Keywords: Crowding; discrete choice; public transit; stated preference

\section{Introduction}

Traditionally, researchers have considered travel time and cost as main attributes that influencing peoples' travel choice behaviors. However, as Tirachini et al. (2013) and Hensher et al. (2013) point out, with the improvement of the understanding of the modal choice problem, there is solid evidence that travelers not only take into account of quantitative attributes such as travel time and cost, but also qualitative aspects that may influence the experience of traveling, such as crowding, reliability, etc. Because of the high density of passengers in carriages of public transit, there may be many effects on passenger well-being, such as anxiety, stress, feelings of exhaustion, reduction of perceived security, and so on. 
Because there are so many effects of crowding on traveler well-being, it is necessary to determine how much travelers are willing to pay to reduce the crowding in carriages of public transit. Therefore, this paper attempts to determine the influences of crowding in carriages of public transit and if there is difference between passenger viewpoints on crowding in metro cars and buses.

As pointed by Zhan (2016), in Chinese high-education regions, the university campus is a special community in which the high student density generates a large and significant trip demand. Therefore, exploring and understanding college students' evaluation of the impact of public transit are the basic supports for transportation development strategies policies and planning.

\section{Literature Review}

Crowding on public transit reduces the probability that passengers will find a seat in carriages and prevents individuals from using travel time for other activities effectively (reading, rest, etc.). Congestion in public transit also may induce security fears, increase noise levels, and reduce hygiene. All of these effect increase personal stress and dissatisfaction (O'Regan and Buckley 2003; Evans and Wener 2007; Mahudin et al. 2011; Mahudin et al. 2012; Li and Hensher 2013). Theyf also may affect traveler path choice of public transportation (Kim et al. 2016).

Noting widespread dissatisfaction with crowding in bus or metro cars, a considerable number of studies have been carried out to determine the effects of crowding. Most analyzed the valuation of crowding in public transportation with discrete choice models. Generally, there are two discrete choice models, the constant value per trip model and the multiplier value model. The constant value per trip model assumes that the crowding effect is irrespective of the duration of travel; the travel time multiplier value model assumes that the crowding effect is proportional to travel time. In addition to discrete choice models, there are other methods used to analyze the value of crowding.

\section{Constant Value per Trip Model}

Cantwell et al. (2009) divided the crowding conditions on trains and buses into five segments-very crowded, somewhat crowded, neither crowded nor uncrowded, somewhat uncrowded, and very uncrowded. It was found that the ratio between the valuation of train crowding and bus crowding was 1.4 , which indicates that users would derive a greater benefit from a reduction in crowding. Basu and Hunt (2012) defined five levels of in-vehicle crowding in a qualitative manner and found the in-vehicle valuations (in Indian Rupees) to be 0.32 for light, 0.46 for moderate, 0.54 for heavy, and 0.59 for very heavy, adopting very light crowding as the benchmark. 


\section{Multiplier Value Model}

Accent (2006) provided multi-level qualitative descriptions to crudely specify in-vehicle crowding, that is, seat flip uncrowded, seat flip crowded, seat perch uncrowded, seat perch crowded, stand uncrowded, stand lean, and stand crowded. The multipliers of these conditions varied from 1.0-2.14. Douglas and Karpouzis (2006) estimated the passenger cost of on-train crowding with Stated Preference (SP) data, in which eight levels of crowding were provided (uncrowded seat, crowded seat, stand up to 10 minutes, stand 15 minutes, stand 20 minutes or longer, crush stand up to 10 minutes, crush stand 15 minutes, crush stand 20 minutes or longer). The relative valuation compared to uncrowded seating varied from 1.17-2.52. Furthermore, gender was found to be an influence; females had a higher cost associated with standing in crushing conditions than males.

The written descriptions of in-vehicle crowding in Mott (2007) were plenty of seats, a few seats available, no seats available and a few standees, and no seats and denselypacked. Also, the paper divided travelers into seven groups-traders only, commuters, non-commuters, car available, non-car available, up to 40 minutes, and over 40 minutes. The multipliers varied from 1.00-3.01 for commuters, and the others were similar.

MVA Consultancy (2008) specified in-vehicle crowding with standee density (standees per square meter) and analyzed seating multipliers and standing multipliers. The seating multipliers and standing multipliers for business travelers varied from 1.00-1.81 and 1.91-2.16, respectively, when the standee density increased from 0 to 6 passengers per square meter $\left(\mathrm{m}^{2}\right)$. Non-business travelers tended to have somewhat low multipliers.

Lu et al. (2008) conducted an SP experiment in Greater Manchester in 2005 in which crowding was shown with combinations of probability of standing and length of time (for example, 2 out of 5 times standing for an entire journey). Within the multinomial logit (MNL) model, the value of crowding was estimated at 12.05 pence per person minute, which is more than twice the value of in-vehicle time. Whelan and Crockett (2009) estimated of the value of overcrowding in trains with an SP survey. To describe and present all attributes in an objective and quantifiable way with a minimal scope for differences in interpretation, they developed a combination of verbal and graphical stimulus material for use in the SP study. The results showed that there is a linear relationship between time multipliers and standee density and found that journey purpose, distance, and income had a significant impacts on time multipliers.

Hensher et al. (2011) described crowding attribute levels by mode with seats occupied and number of standees and showed that with the rise in the number of standees, the crowding utility increases with a quadratic function and the crowding valuation of metro is slightly higher than that of bus. Wang and Legaspi (2012) described in-vehicle crowding with a load factor, in which the multipliers were functions of load factor and standing time. For example, the cost of in-vehicle crowding per minute for standing 10-20 minutes was smaller than that for standing 20 minutes or more.

Haywood and Koning $(2013,2015)$ specified in-vehicle crowding with passenger density, which is different from standee density. The multipliers ranged from 1.00-1.57, and 
standee density ranged from 0-6 pass $/ \mathrm{m}^{2}$. Kroes et al. (2013) presented in-vehicle crowding levels by mode with load factor, which ranged from $25-250 \%$. Tirachini et al. (2013) studied the relationship between multipliers and load factor and between multipliers and standee density. It was found that there was a linear relationship between multipliers and standee density, and the multipliers reached approximately 3 when the standee density was 4 standees $/ \mathrm{m}^{2}$.

Vovsha et al. (2014) quantified in-vehicle crowding with seven categories associated with the probability of having a seat and the inability to board when crowding reaches an extreme level. Data in that paper shows that trip purpose, age, travel mode, income, and trip length had influence on multipliers, although all these effects were not striking. Batarce et al. (2015) evaluated time multipliers with SP data and RP data; results shows that the time multipliers at $5-6$ standees $/ \mathrm{m}^{2}$ is 2.1 times the multipliers at $1-2 \mathrm{standees} /$ $\mathrm{m}^{2}$.

\section{Other Methods}

Cantwell et al. (2009) analyzed the relationship between crowding in public transport and commute satisfaction with a linear regression analysis. Haywood and Koning (2011) investigated the impact of travel comfort on the utility of subway users with an ordered logit model and found that metro passengers were prepared to travel, on average, eight minutes longer per trip to reduce the high peak-hour level of crowding to the substantially lower level of crowding experienced outside the peaks. This is roughly equivalent to a value of about 1.5 euros per trip, which is clearly non-negligible. Also, it was found that certain individual characteristics (age, socioeconomic status, etc.) significantly influence willingness to pay. Prud'homme et al. (2012) estimated the disutility of crowding with the ordered logit model.

Two papers review the literature about crowding on public transit. Li and Hensher (2011) reviewed public transport crowding valuation research using studies conducted in the UK, the U.S., Australia, and Israel and identified three measures to value crowding - a travel time multiplier, a monetary value per time unit, and a monetary value per trip-but they did not provide a comparison between their performances. They also described associated ways to represent crowding in SP experiments and implied that SP research is the preferred way of conducting valuation research for crowding. Despite the highly-different characteristics of the studies reviewed, they noted that all reported that crowding would increase the value of travel time savings, which, according to them, "can be viewed as an additional component of generalized time."

Wardman and Whelan (2011) reviewed evidence from British experience of the valuation of rail crowding obtained over 20 years from 17 studies in a meta-analysis project and found that the seating multiplier averages 1.19 and the standing multiplier averages 2.32 , which implies that the disutility of travel in a very crowded situation for standees is more than twice as much as compared with a situation when seats are available. 
Although many studies on crowding have been conducted, most have been in developed countries or areas. There is still little research on crowding in China, especially based on passenger perception. Li and Hensher (2013) argued that the benchmarks that define the unacceptable crowding levels vary across different countries or regions. For example, four standees per $\mathrm{m}^{2}$ is the benchmark for Australia (Diec et al. 2010), a number that increases to five standees per $\mathrm{m}^{2}$ for the U.S. (Furth et al. 2006).

Furthermore, as Das and Pandit (2013) pointed out, "Since the service delivery environment differs between developed and developing nations, the user perception of service quality varies between these economic regions"; as a result, research results from developed countries or areas not suitable for China.

\section{Experiment Design and Data Collection}

In this study, we analyzed the valuation of in-vehicle crowding with multinomial logit model.

Although Turner et al. (2004), Cox et al. (2006), and Li and Hensher. (2013) argued that there is a disconnection or gap between objective and subjective measures of crowding, there are still many debates on the subjective measures of crowding. The objective measures, such as the number of standing passengers per square meter, are still an appropriate representation of passenger subjective measure of crowding.

To estimate the economic value passengers place on crowding in a metro car or bus, this study conducted an SP choice experiment in which a sample of passengers was offered a series of choices between two (or more) hypothetical alternative public transport services. These services differed in some key characteristics.

To ensure that the interviewees could easily understand the scenarios presented to them and to ensure that the key attributes of the scenarios were presented in a quantifiable manner, the experiment was designed with a two-stage process-a pilot survey and a formal survey. In the pilot survey stage, several choice attributes were considered for inclusion within the SP exercises: (1) level of crowding in metro car, (2) waiting time on subway platform, (3) fare, (4) journey time in metro car, (5) walking time from origination to subway platform and from platform to destination, and (6) interchange.

As mentioned, there are many ways to represent in-vehicle crowding, such as load factor, standee density, combinations of probability of standing and length of standing time, and so on. Because the average commuting time in Guangzhou exceeds 45 minutes during rush hour, public transportation can be so overcrowded that the door is blocked by passengers, sometimes making boarding and alighting difficult; thus, it is entirely possible for passengers to stand at the same level of overcrowding for the entire trip. Therefore, in this study, we did not represent in-vehicle crowding with the probability of standing. Since the same load factor may have different levels of crowding across different types of trains with varying amounts of seating and standing space, this 
study describes crowding with the objective standard measure of number of standing passengers per square meter.

It is difficult for respondents to identify in-vehicle crowdedness when presented only with standee density, e.g., 6 standees $/ \mathrm{m}^{2}$. Therefore, to enable respondents to have a clear and consistent understanding of the levels of crowding, in-vehicle crowding (or standee density) was described using the linguistic notion method. Based on related research achievements by Jiang et al. (2012) and Qin and Jia $(2012,2014)$, crowding levels were described as shown in Table 1.

TABLE 1.

Standee Density and Crowding Description in Metro Cars and Bus Carriages

\begin{tabular}{|l|l|l|}
\hline Crowding Conditions & Standee Density & \multicolumn{1}{c|}{ Crowding Description } \\
\hline Crowding1 & 0 person $/ \mathrm{m}^{2}$ & No person standing inside car \\
\hline Crowding2 & 1 person $/ \mathrm{m}^{2}$ & No seat, but can circulate freely \\
\hline Crowding3 & 4 persons $/ \mathrm{m}^{2}$ & $\begin{array}{l}\text { Some restrictions in movement, high } \\
\text { probability of physical contact }\end{array}$ \\
\hline Crowding4 & 7 persons $/ \mathrm{m}^{2}$ & $\begin{array}{l}\text { Impossible movement, difficult to get } \\
\text { on/off car }\end{array}$ \\
\hline
\end{tabular}

An example of the layout of the SP question is shown in Figure 1. A focus group of 4 people was asked to evaluate the interpretability of the question. All noted that there were too many attributes and that it was easy to get confused. Therefore, after discussion, the number of attributes was decreased. The attributes and level of each attribute are shown in Table 2.

Since the average commuting time in Guangzhou is around 50 minutes, four levels were set for this attribute-30 minutes, 40 minutes, 45 minutes, and 60 minutes. For standee density, four levels were used based on reality, three levels for fare, and three levels for waiting time on platform.

FIGURE 1.

Example SP question of pilot survey

\begin{tabular}{|c|c|}
\hline \multicolumn{2}{|c|}{ Situation 1} \\
\hline Metro A & Metro B \\
\hline $\begin{array}{l}\text { Some restriction in movement, high probability of } \\
\text { physical contact }\end{array}$ & No seat, but can circulate freely \\
\hline Waiting time is $\mathbf{5}$ minutes & Waiting time is 10 minutes \\
\hline Journey time is $\mathbf{3 5}$ minutes & Journey time is $\mathbf{4 0}$ minutes \\
\hline Walking time is 8 minutes & Walking time is 6 minutes \\
\hline Fare is $¥ 2$ & Fare is $¥ 3$ \\
\hline Don't need to transfer & Have to transfer for a time \\
\hline \multicolumn{2}{|c|}{ Q: Which metro do you prefer? } \\
\hline$\square$ Prefer A & $\square$ Prefer B \\
\hline
\end{tabular}

TABLE 2.

Levels of Attributes in Formal Investigation

\begin{tabular}{|l|l|}
\hline \multicolumn{1}{|c|}{ Attribute } & \multicolumn{1}{c|}{ Level of Attribute } \\
\hline Journey time in metro car & i) $30 \mathrm{~min}$, ii) $40 \mathrm{~min}$, iii) $45 \mathrm{~min}$, iv) $60 \mathrm{~min}$ \\
\hline Standee density & i) 0 person $/ \mathrm{m}^{2}$, ii) 1 person $/ \mathrm{m}^{2}$, iii) 4 persons $/ \mathrm{m}^{2}$, iv) 7 persons $/ \mathrm{m}^{2}$ \\
\hline Fare & i) $¥ 3$, ii) $¥ 4$, iii) $¥ 5$ \\
\hline Waiting time on platform & i) $5 \mathrm{~min}$, ii) $10 \mathrm{~min}, \mathrm{iii}) 15 \mathrm{~min}$ \\
\hline
\end{tabular}


With attributes and levels mentioned in Table 2 , a total of $144(4 \times 4 \times 3 \times 3)$ profiles (or a virtual transit system) could be formed, but it was unrealistic and unnecessary to ask the respondents to evaluate all the profiles, and orthogonal design was not used because it would produce too many profiles, especially when the goal is to induce interactions between crowding and travel time.

To gain the separate effects and interactions of attributes, the DOE platform in the software JMP was used to create a choice design. To create an effective design, information about all the attributes and their levels was needed. Therefore, a sample survey was created for a pilot study, and prior information was obtained with JMP. The core of the survey was a set of SP questions in which respondents were asked to sort three hypothetical journeys that differed in terms of on-train travel time, waiting time, on-train crowding, and ticket fare according to their preferences. Respondents were asked to make their choice in the context of the trip they were making. Each respondent undertook one comparison. A total of 16 choice sets similar to Appendix II were developed. Times and crowding were varied systematically so that the effect of travel time and crowding could be established statistically. The choice sets were used for metro and bus.

College students were selected as the focus of the study. Because the demographic characteristics of college students is somewhat different from working people, except for the SP choice investigation, some demographic characteristics were also investigated, as shown in Figure 2.
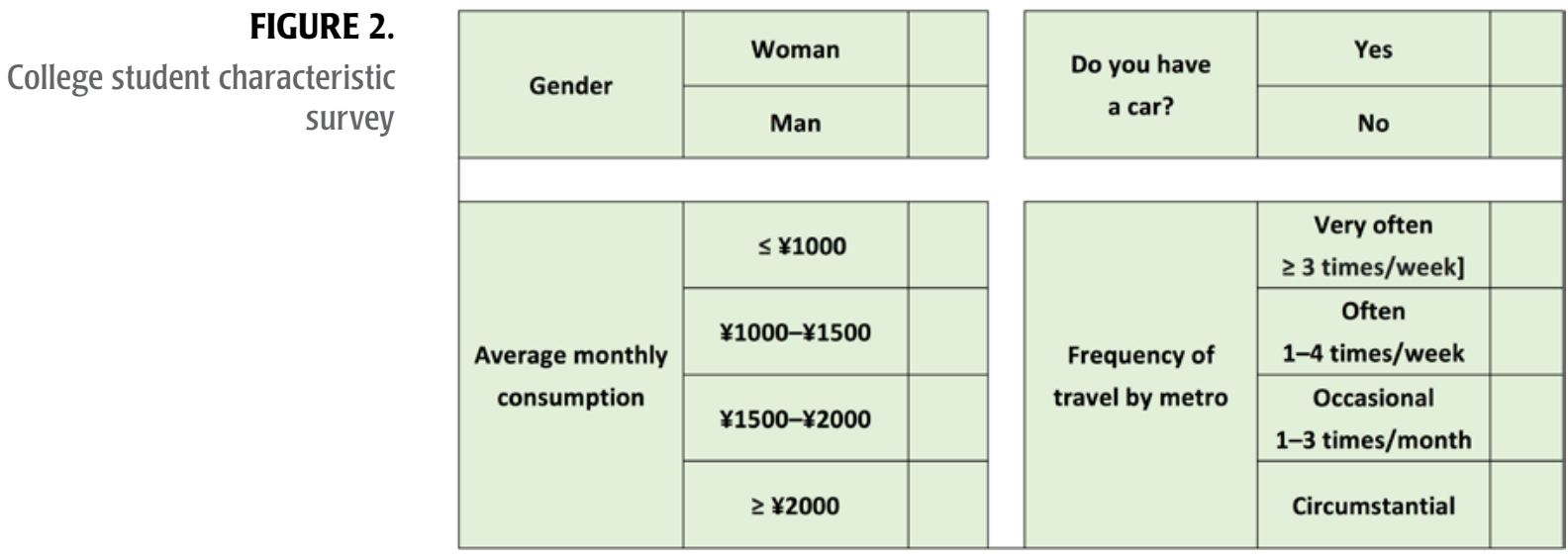

\section{Data Analysis}

\section{Sample Size and Descriptive Analysis}

The surveys were undertaken between April and May 2015 for metro and between July and August 2015 for bus on the main campus of South China University of Technology in downtown Guangzhou. Each respondent was asked to evaluate only one choice set in Appendix II, and each choice set was evaluated 23 times for metro and 13 times 
for bus, resulting in 368 valid surveys for metro and 208 for bus. Table 3 shows the socioeconomic characteristics of the college students from the data obtained in the SP survey.

TABLE 3.

Distribution of Sample into Different Socio-Economic

Groups

\begin{tabular}{|l|l|r|r|}
\hline \multirow{2}{*}{ Category } & \multicolumn{2}{|c|}{ Sub-category } & \multicolumn{2}{c|}{ Percentages (\%) } \\
\cline { 2 - 4 } Gender & Woman & \multicolumn{1}{c|}{ Metro } & \multicolumn{1}{c|}{ Bus } \\
\cline { 2 - 4 } & Man & $48.90 \%$ & $40.10 \%$ \\
\hline \multirow{4}{*}{ Do you have a car? } & Yes & $51.10 \%$ & $59.90 \%$ \\
\cline { 2 - 4 } & No & $0.00 \%$ & $0.00 \%$ \\
\hline \multirow{4}{*}{$\begin{array}{l}\text { Average monthly } \\
\text { consumption }\end{array}$} & $\leq ¥ 1000$ & $100.00 \%$ & $100.00 \%$ \\
\cline { 2 - 4 } & $¥ 1000-¥ 1500$ & $18.80 \%$ & $22.77 \%$ \\
\cline { 2 - 4 } & $¥ 1500-¥ 2000$ & $32.60 \%$ & $38.12 \%$ \\
\cline { 2 - 4 } & $\geq ¥ 2000$ & $39.10 \%$ & $33.66 \%$ \\
\hline \multirow{4}{*}{$\begin{array}{l}\text { Frequency of travel } \\
\text { by metro }\end{array}$} & Very often $(\geq 3$ times/week) & $51.60 \%$ & $43.56 \%$ \\
\cline { 2 - 4 } & Often (1-4 times/week) & $36.70 \%$ & $48.02 \%$ \\
\cline { 2 - 4 } & Occasional (1-3 times/month) & $11.70 \%$ & $8.42 \%$ \\
\cline { 2 - 4 } & Circumstantial & $0.00 \%$ & $0.00 \%$ \\
\hline
\end{tabular}

In total, $48.90 \%$ of metro respondents and $40.10 \%$ of bus respondents were women. A total of $88.30 \%$ traveled by metro more than once a week, and $91.58 \%$ traveled by bus more than once a week. All respondents were familiar with metro and bus.

\section{Modeling and Discussion of Results}

The collected SP data were analyzed with the multinomial logit model in which decision-makers are assumed to make choices based on the concept of utility maximization.

\section{Model 1 - Single Constant Value Model}

The analysis began with the estimation of the single constant value per trip model, as specified in Equation 1:

$$
U_{i}=\alpha_{0} \mathrm{IVT}+\alpha_{1} \text { Fare }+\alpha_{2} \text { Wait }+\sum_{i=1}^{4} \beta_{i} D_{i}+\varepsilon_{i}
$$

Where $U_{i}$ is the utility of alternative $I$, Fare is the journey ticket price, IVT is the journey time in car (minutes), Wait is the waiting time on the platform, $D_{i}$ is a vector of four dummy variables representing the four different levels of crowding shown in Table 1 , and $\varepsilon_{i}$ is the unobserved part of utility. $\alpha_{0}, \alpha_{1}, \alpha_{2}, \beta_{1}, \beta_{2}, \beta_{3}, \beta_{4}$ are the coefficients to be estimated.

The choice probability that alternative $i$ over alternative $j$ can be expressed with $P_{i}=\operatorname{Pr} o b\left(U_{i}>U_{j}, \forall j \neq i\right)$. Since the choice probability that alternative $i$ is selected 
depends only on the difference in utility, but not its absolute level, we normalized $\beta_{1}$ to zero, and $\beta_{2}, \beta_{3}, \beta_{4}$ can be interpreted as being to $\beta_{1}$.

The results of the single constant value per trip model runs are shown in Table 4.

TABLE 4.

Results of Single Constant Value per Trip Model

\begin{tabular}{|l|l|r|r|r|r|r|r|}
\hline & Parameters & \multicolumn{1}{|c|}{$\boldsymbol{\beta}_{2}$} & \multicolumn{1}{c|}{$\boldsymbol{\beta}_{3}$} & \multicolumn{1}{c|}{$\boldsymbol{\beta}_{4}$} & \multicolumn{1}{c|}{$\boldsymbol{\alpha}_{0}$} & \multicolumn{1}{c|}{$\boldsymbol{\alpha}_{1}$} & \multicolumn{1}{c|}{$\boldsymbol{\alpha}_{2}$} \\
\hline \multirow{4}{*}{ Metro } & Coefficient & $-1.53515^{*}$ & $-1.89828^{*}$ & $-3.99241^{*}$ & $-0.09653^{*}$ & $-0.23946^{*}$ & $-0.11975^{*}$ \\
\cline { 2 - 8 } & Standard Error & 0.16314 & 0.18559 & 0.27845 & 0.00982 & 0.06581 & 0.01715 \\
\cline { 2 - 8 } & $z$ & -9.41 & -10.23 & -14.34 & -9.83 & -3.64 & -6.98 \\
\cline { 2 - 8 } & Prob. $|z|>Z^{* * *}$ & 0.0000 & 0.0000 & 0.0000 & 0.0000 & 0.0003 & 0.0000 \\
\hline \multirow{4}{*}{ Bus } & Coefficient & $-1.34293^{*}$ & $-1.64462^{*}$ & $-3.12547^{*}$ & $-.07165^{*}$ & $-17247^{* *}$ & $-.05972^{*}$ \\
\cline { 2 - 8 } & Standard Error & 0.20071 & 0.21929 & 0.29068 & 0.01114 & 0.08094 & 0.01943 \\
\cline { 2 - 8 } & $z$ & -6.69 & -7.50 & -10.75 & -6.43 & -2.13 & -3.07 \\
\cline { 2 - 8 } & Prob. $|z|>Z^{* * *}$ & 0.0000 & 0.0000 & 0.0000 & .0000 & 0.0331 & 0.0021 \\
\hline
\end{tabular}

*Significant at $10 \%$ level

** Significant at $5 \%$ level

***Significant at $1 \%$ level

Fit statistics for bus: $R^{2}=0.3208, F=268.3921$

Fit statistics for metro: $R^{2}=0.3417, F=419.4775$

As shown in Table 4 , all the coefficients were significant at the $95 \%$ confidence level (Prob. $|z|>Z^{*}<<0.05$ ). The estimated coefficients in Table 4 provide information on the value of crowding levels.

Dividing the coefficients in Table 4 except for $\alpha_{1}$ by $\alpha_{1}$, we obtained the coefficients' value expressed by ticket price (RMB Yuan), as shown in Figure 3 , which indicates that the values of crowding in bus are slightly larger than those in metro.

FIGURE 3.

Monetary values of different levels of crowding (RMB Yuan)

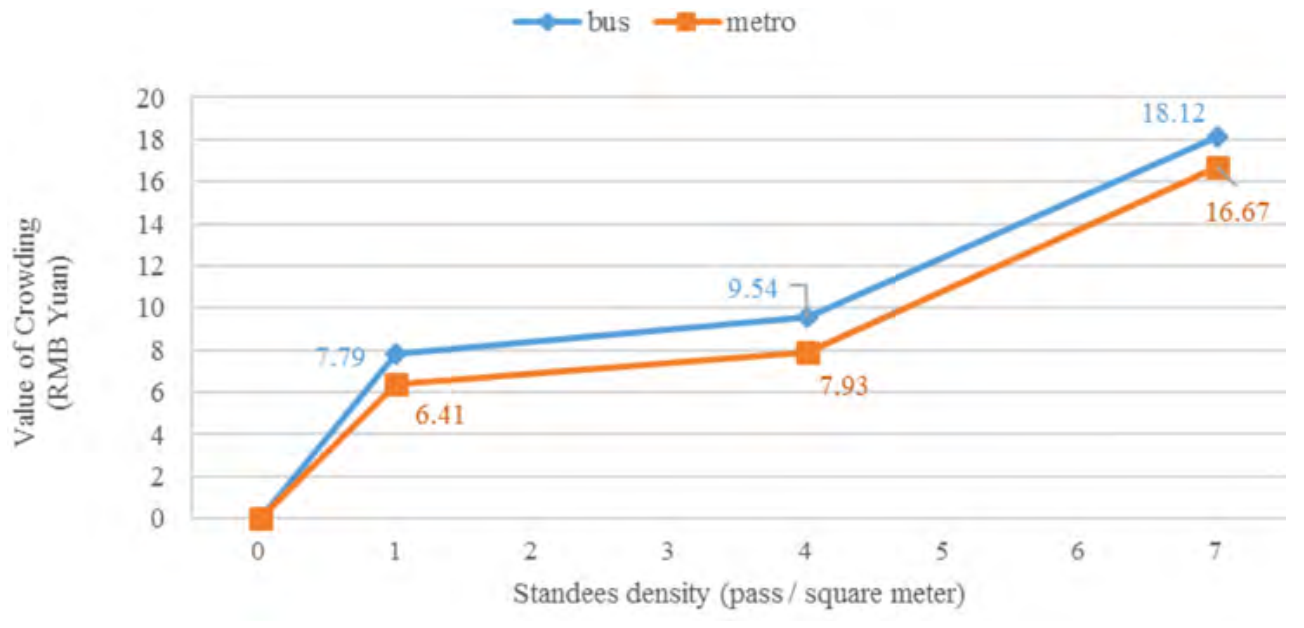

Crowding's value in metroincreases to $¥ 6.41$ if passengers have to stand, even though the standee is free to circulate. But the value increases slowly as the standee density increases when it is less than 4 persons $/ \mathrm{m}^{2}$ (no high probability of physical contact). The disutility of crowding increases rapidly as the standee density increases when it 
is more than 4 persons $/ \mathrm{m}^{2}$ - that is, the slope of the line between 4 persons $/ \mathrm{m}^{2}$ and 7 persons $/ \mathrm{m}^{2}$ (7.13) is much larger than that between 1 person $/ \mathrm{m}^{2}$ and 4 persons $/ \mathrm{m}^{2}(0.97)$. Crowding's value for bus is almost the same as that for metro.

Dividing the coefficients in Table 4 except for $\alpha_{0}$ by $\alpha_{0}$, we obtained the coefficients' value expressed by journey time (in minutes), as shown in Figure 4.

FIGURE 4.

Values of different levels of crowding expressed by IVT

(min)

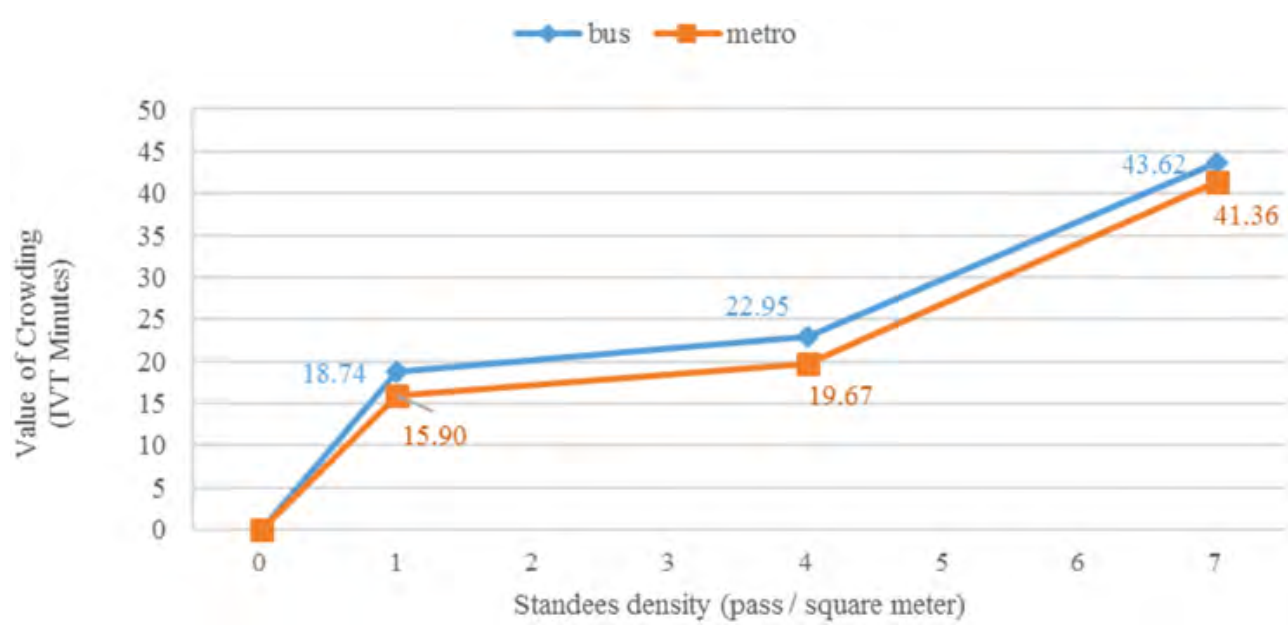

Also as shown in Figure 4, the characteristic of crowding's value (expressed by journey time) in a bus is almost the same as that in a metro, except that crowding's values in a bus are slightly larger than that in a metro. Crowding's value in a metro car increases to 15.90 minutes if passengers have to stand and to 41.36 minutes when standee density increases to 7 standees $/ \mathrm{m}^{2}$. Crowding's value in a bus increases to 18.74 minutes if passengers have to stand and to $\mathbf{4 3 . 6 2}$ minutes when standee density increases to 7 standees $/ \mathrm{m}^{2}$.

Therefore, we can conclude that passengers dislike crowding strongly, especially when there is a high probability of physical contact.

\section{Model 2. Travel Time Multiplier Model}

The single constant value model assumes that the crowding effect is irrespective of the duration of travel. Kroes et al. (2013) argued that the longer the journey, the more important it is to travel comfortably, so the travel time multiplier value model, which assumes that the crowding effect is proportional to the travel time, seems intuitively more appealing. Therefore, we analyzed the effect of crowding in a metro car with the travel time multiplier model. The equation can be expressed as:

$$
U_{i}=\alpha_{1} \text { Fare }+\alpha_{2} \text { Wait }+\sum_{i=1}^{4} \gamma_{i} D_{i} \cdot \operatorname{IVT}+\varepsilon_{i}
$$

Where the meanings of the parameters $\left(U_{i}\right.$, Fare, Wait, IVT, $\left.D_{i}, \varepsilon_{i}\right)$ are the same as in Equation 1. $\alpha_{1}, \alpha_{2}, \gamma_{1}, \gamma_{2}, \gamma_{3}, \gamma_{4}$ are the coefficients to be estimated. The results of the travel time multiplier value model runs are shown in Table 5. 
TABLE 5.

Results of Travel Time Multiplier Value Model

\begin{tabular}{|l|l|r|r|r|r|r|r|}
\hline & \multicolumn{1}{|c|}{ Parameters } & \multicolumn{1}{c|}{$\gamma_{1}$} & \multicolumn{1}{c|}{$\gamma_{2}$} & \multicolumn{1}{c|}{$\gamma_{3}$} & \multicolumn{1}{c|}{$\gamma_{4}$} & \multicolumn{1}{c|}{$\alpha_{1}$} & \multicolumn{1}{c|}{$\alpha_{2}$} \\
\hline \multirow{4}{*}{ Metro } & Coefficient & $-0.05682 \mathrm{~A}^{*}$ & $-0.08501^{*}$ & $-0.09200^{*}$ & $-0.14836^{*}$ & $-0.20441^{*}$ & $-0.10619^{*}$ \\
\cline { 2 - 8 } & Standard Error & 0.00812 & 0.00923 & 0.00997 & 0.01220 & 0.06483 & 0.01620 \\
\cline { 2 - 8 } & $\mathrm{z}$ & -7.00 & -9.21 & -9.23 & -12.16 & -3.15 & -6.56 \\
\cline { 2 - 8 } & Prob. $|\mathrm{z}|>\mathrm{Z}^{* * *}$ & 0.0000 & 0.0000 & 0.0000 & 0.0000 & 0.0016 & 0.0000 \\
\hline \multirow{3}{*}{ Bus } & Coefficient & $-0.03823^{*}$ & $-0.06344^{*}$ & $-0.07051^{*}$ & $-0.10925^{*}$ & $-0.14882^{* * *}$ & $-0.05493^{*}$ \\
\cline { 2 - 8 } & Standard Error & 0.00970 & 0.01081 & 0.01163 & 0.01303 & 0.08080 & 0.01880 \\
\cline { 2 - 8 } & $\mathrm{z}$ & -3.94 & -5.87 & -6.06 & -8.38 & -1.84 & -2.92 \\
\cline { 2 - 8 } & Prob. $|\mathrm{z}|>Z^{* * *}$ & 0.0001 & 0.0000 & 0.0000 & 0.0000 & 0.0655 & 0.0035 \\
\hline
\end{tabular}

*Significant at $10 \%$ level

***Significant at $1 \%$ level

Fit statistics for bus: $R^{2}=0.3192, F=270.0541$

Fit statistics for metro: $R^{2}=0.2913, F=428.0019$

As shown in Table 5, all the coefficients are significant at the $95 \%$ confidence level (Prob. $|z|>Z^{*}<<0.05$ ), except $\alpha_{1}$ of bus, which is significant at the $90 \%$ confidence level. Dividing the coefficients in Table 5 except for $\alpha_{1}$ by $\alpha_{1}$, we obtained the coefficients' value expressed by monetary value (RMB Yuan), as shown in Figure 5.

FIGURE 5.

Relationship between value of time multiplier and standee density in metro car

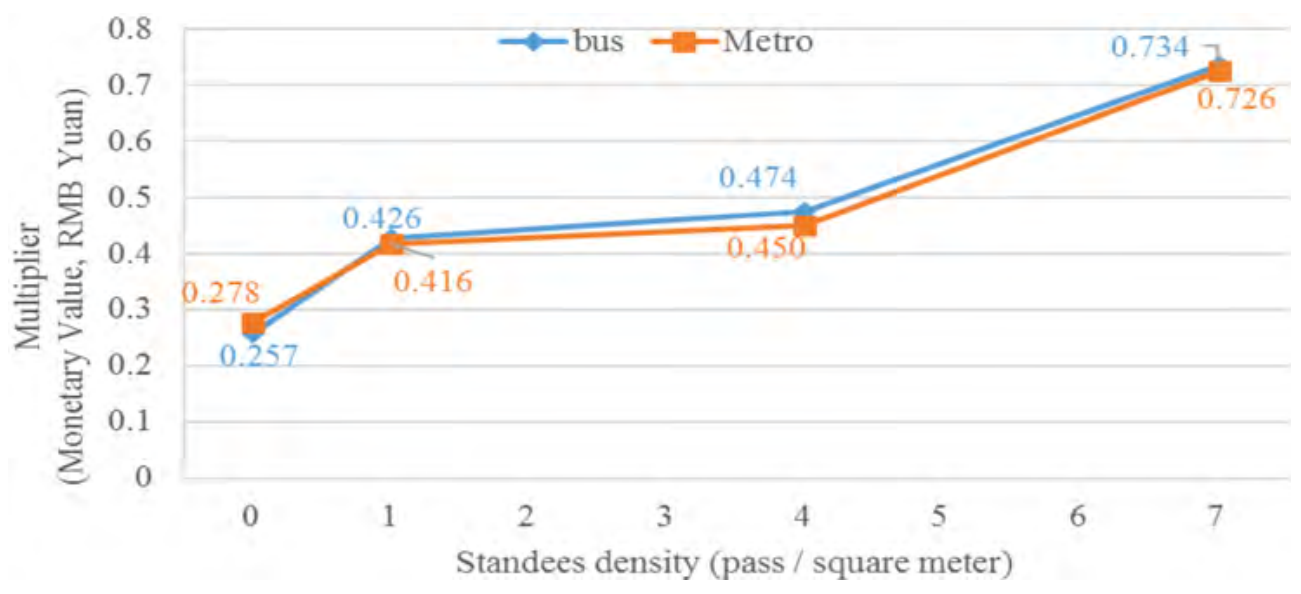

It can be easily determined from Figure 5 that the difference between the bus multiplier and the metro multiplier is extremely small.

To evaluate the effect of crowding more clearly, it was necessary to use relative multipliers. Therefore, we chose a multiplier of bus when the standee density was 0 standees $/ \mathrm{m}^{2}$ as the reference value and divided all multipliers of bus by the reference value to obtain the relative multipliers of bus, and did the same for multipliers of metro. The relative multipliers are shown in Figure 6. 
FIGURE 6.

Relative multipliers compared with reference values

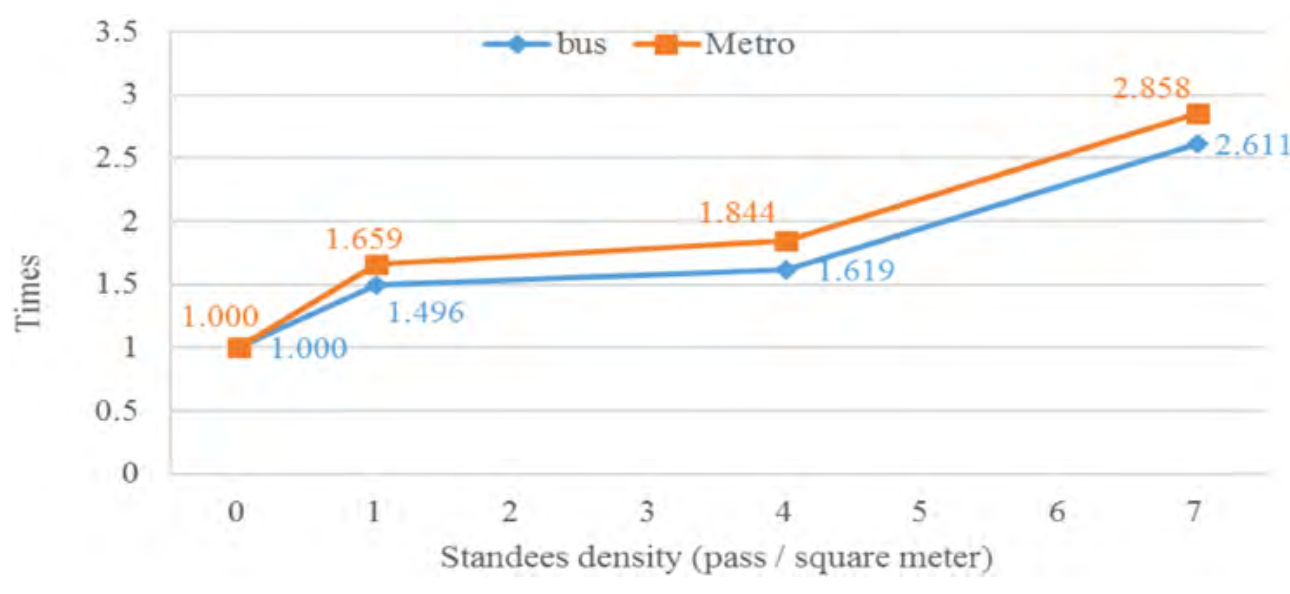

The relative multipliers value increases slowly as the standee density increases when it is less than 4 persons $/ \mathrm{m}^{2}$ (no high probability of physical contact) and increases rapidly when the standee density is larger than 4 persons $/ \mathrm{m}^{2}$. The relative multiplier of metro when the standee density is 7 persons $/ \mathrm{m}^{2}$ is 2.858 times that when the standee density is 0 persons $/ \mathrm{m}^{2}$ and is 2.611 for bus.

\section{Conclusions}

Using data from a survey of college students in Guangzhou, we proposed individual trade-offs among travel time, cost, waiting time, and passenger density and found that crowding is a non-negligible factor that affecting a traveler's utility and mode choice. For example, crowding's value in a metro car increases to 15.90 minutes if passengers have to stand and to 41.36 minutes when standee density increases to 7 persons $/ \mathrm{m}^{2}$. Since the average one-way commuting time in Guangzhou is about $\mathbf{4 5}$ minutes, crowding's value is obviously non-ignorable. Furthermore, there is non-linear relationship between the disutility of crowding and standee density. This disutility increases at a modest rate as the standee density increases when it is no more than 4 persons $/ \mathrm{m}^{2}$ and increases rapidly when standee density is more than 4 persons $/ \mathrm{m}^{2}$. Therefore, 4 persons $/ \mathrm{m}^{2}$ (where there is a high probability of physical contact) is a critical point of disutility. Furthermore, there is only small difference between values of crowding in bus carriages and metro cars.

This conclusion is different from that of other published papers. The ratio that compares the train crowding coefficient with the bus crowding coefficient equals to 1.4 in Cantwell et al. (2009, and the ratios are larger than 1 in Vovsha et al. (2014). However, the ratio in this study fluctuated around 1. In fact, the ratios vary from 1.09 to 1.21 for the single constant value model and 0.92 to 1.05 for the travel time multiplier model. Since the travel time multiplier model seems intuitively more appealing, we can conclude from the data in this study that there is a negligible difference between crowding's valuation in metro and bus in the same crowded situations.

MVA Consultancy (2008), Tirachini et al. (2013), and Whelan and Crockett (2009) concluded that there is a linear relationship between the cost of crowding in a carriage 
and standee density. However, the results in this study show a high cost for standing relative to sitting (time is valued 1.5-1.65 times higher) but little extra cost for standing in moderately-crowded conditions. Crush standing, however, nearly doubles the time multiplier. The results in this study are quite different from previous studies. When the carriage is not extremely crowded (standee density less than 4 standees $/ \mathrm{m}^{2}$ ), there is little difference among the multipliers in this study and the multipliers in previous studies, but there are great differences among the multipliers in this study and the multipliers in previous studies. For example, the time multiplier for metro is 2.858 in a crush standing condition, and the time multipliers in MVA Consultancy (2008) and Whelan and Crockett (2009) are only around 2.

Traditional planning practices usually focus on quantitative factors (travel time, cost, etc.). Although some planners in China have recognized the existence of crowding in cars of public transit, they have overlooked and undervalued its impact. The conclusion in this study is particularly important for transit planning because metro's service quality varies greatly and because nearly all transit service quality decisions are made in a formal planning process. Our results can be used during the planning and appraisal stages of public transport projects. For example, in the design of a bus or metro network, planners should focus not only on traditional factors such as traveling time, walking time, ticket price, etc., but also on the impact of crowding in cars. In the analysis of network equilibrium, researchers should also take into account the impact of crowding in public transit.

In this study, survey data were obtained only from college students, and results perhaps can be generalized to others, such as commuters and older adults. However, since demographic characteristics may affect the evaluation of crowding in public transit, it is necessary to obtain more survey data from other groups to analyze the impact of crowding in carriages and determine the differences between the cost of crowding in bus and metro cars.

\section{Acknowledgment}

This paper was sponsored by the National Natural Science Foundation of China (Grant No. 51378222) and Guangdong Provincial Science-technology Planning Projects (2013B010401009).

\section{References}

Accent. 2006. "Rail Customer Valuations of Sitting, Standing and Crowding." Prepared for Transport for London.

Batarce, Marco, Juan Carlos Muñoz, Juan de Dios Ortuzar, Sebastián Raveau, Carlos Mojica, and Ramiro Alberto Ríos. 2015. "Valuing Crowding in Public Transport Systems Using Mixed Stated/Revealed Preferences Data: The Case of Santiago." TRB 94th Annual Meeting Compendium of Papers, Washington DC. 
Basu, Debasis, and John Douglas Hunt. 2012. "Valuing of Attributes Influencing the Attractiveness of Suburban Train Service in Mumbai City: A Stated Preference Approach." Transportation Research Part A: Policy and Practice, 46(9): 1465-1476.

Cantwell, Mairead, Brian Caulfield, and Margaret O'Mahony. 2009. "Examining the Factors that Impact Public Transport Commuting Satisfaction." Journal of Public Transportation, 12(2): 1-21.

Cox, Tom, Jonathan Houdmont, and Amanda Griffiths. 2006. "Rail Passenger Crowding, Stress, Health and Safety in Britain." Transportation Research Part A: Policy and Practice, 40(3): 244-258.

Das, Shreya, and Debapratim Pandit. 2013. "Importance of User Perception in Evaluating Level of Service for Bus Transit for a Developing Country like India: A Review." Transport Reviews, 33(4): 402-420.

Diec, J., S. Coxon, and A. de Bono. 2010. “Designing a Public Train Station Shelter to Minimise Anti-Social Behaviour and Crime in Melbourne's Metropolitan Rail Environment." $33^{\text {rd }}$ Australasian Transport Research Forum (ATRF), Canberra, ACT, Australia.

Douglas, Neil, and George Karpouzis. 2006. "Estimating the Passenger Cost of Train Overcrowding." 29th Australian Transport Research Forum.

Evans, Gary W., and Richard E. Wener. 2007. "Crowding and Personal Space Invasion on the Train: Please Don't Make Me Sit in the Middle." Journal of Environmental Psychology, 27(1): 90-94.

Faber, Maunsell, and Mott MacDonald. 2007. "Rail Overcrowding, Reliability and Frequency Demand Impacts Project." Prepared for Centro.

Furth, Peter G., Brendon Hemily, Theo H. J. Muller, and James G. Strathman. 2006. "Using Archived AVL-APC Data to Improve Transit Performance and Management." Transportation Research Board of the National Academies, Washington, DC.

Haywood, Luke, and Martin Koning. 2011. "Pushy Parisian Elbows: Evidence on Taste for Travel Comfort." Paris School of Economics, Paris.

Haywood, Luke, and Martin Koning. 2013. "Estimating Crowding Costs in Public Transport." DIW Berlin, German Institute for Economic Research.

Haywood, Luke, and Martin Koning. 2015. "The Distribution of Crowding Costs in Public Transport: New Evidence from Paris." Transportation Research Part A: Policy and Practice, 77: 182-201.

Hensher, David A., John M. Rose, and Andrew T. Collins. 2011. "Identifying Commuter Preferences for Existing Modes and a Proposed Metro in Sydney, Australia with Special Reference to Crowding." Public Transport, 3(2): 109-147.

Hensher, David A., John M. Rose, Waiyan Leong, Alejandro Tirachini, and Zheng Li. 2013. "Choosing Public Transport-Incorporating Richer Behavioural Elements in Modal Choice Models." Transport Reviews, 33(1): 92-106. 
Jiang, Shengchuan, Sun Yifan, and Du Yuchuan. 2012. "Infuence of In-vehicle Congestion Degree on Choice of Public Transit Mode." Journal of Tongji University (Natural Science), 12: 1831-1835.

Kim, Kyung Min, Sung-Pil Hong, Suk-Joon Ko, and Dowon Kim. 2015. “Does Crowding Affect the Path Choice of Metro Passengers?" Transportation Research Part A: Policy and Practice, 77: 292-304.

Kroes, Eric, Marco Kouwenhoven, Laurence Debrincat, and Nicolas Pauget. 2013. "On the Value of Crowding in Public Transport for Île-de-France." International Transport Forum Discussion Paper.

Li, Zheng, and David A. Hensher. 2013. "Crowding in Public Transport: A Review of Objective and Subjective Measures." Journal of Public Transportation, 16(2): 107-134.

Lu, Hui, Tony Fowkes, and Mark Wardman. 2008. "Amending the Incentive for Strategic Bias in Stated Preference Studies: Case Study in Users' Valuation of Rolling Stock." Transportation Research Record, 2049(1): 128-135.

Mahudin, N. D. Mohd, Tom Cox, and A. Griffiths. 2011. "Modelling the Spillover Effects of Rail Passenger Crowding on Individual Well Being and Organisational Behaviour." Urban Transport XVII: Urban Transport and the Environment in the 21st Century: 227-238.

Mahudin, N. D. Mohd, Tom Cox, and Amanda Griffiths. 2012. "Measuring Rail Passenger Crowding: Scale Development and Psychometric Properties." Transportation Research Part F: Traffic Psychology and Behaviour, 15(1): 38-51.

MVA Consultancy. 2008. "Valuation of Overcrowding on Rail Services." Prepared for Department for Transport.

O'Regan, Brendan, and Finian Buckley. 2003. "The Psychological Effects of Commuting in Dublin." Centre for Research in Management Learning and Development Working Paper Series.

Prud'homme, Rémy, Martin Koning, Luc Lenormand, and Anne Fehr. 2012. "Public Transport Congestion Costs: The Case of the Paris Subway." Transport Policy, 21(C): 101-109.

Qin, Feifei. 2014. "Investigating the In-Vehicle Crowding Cost Functions for Public Transit Modes." Mathematical Problems in Engineering, 2014: 1-13.

Qin, Feifei, and Haicheng Jia. 2012. "Remodeling In-Vehicle Crowding Cost Functions for Public Transit." Transportation Research Board 91st Annual Meeting.

Tirachini, Alejandro, David A. Hensher, and John M. Rose. 2013. "Crowding in Public Transport Systems: Effects on Users, Operation and Implications for the Estimation of Demand." Transportation Research Part A: Policy and Practice, 53: 36-52.

Turner, S, E. Corbett, R. O'Hara, and J. White. 2004. “Health and Safety Effects of Rail Crowding: Hazard Identification." Rail Safety and Standards Board. 
Vovsha, Peter, G. S. O. Marcelo, D. William, et al. 2014. "Statistical Analysis of Transit User Preferences including In-Vehicle Crowding and Service Reliability." TRB 2014 Annual Meeting.

Wang, B, and J. Legaspi. 2012. “Developing a Train Crowding Economic Costing Model and Estimating Passenger Crowding Cost of Sydney CityRail network." $35^{\text {th }}$ Australasian Transport Research Forum (ATRF), Perth, Australia.

Wardman, Mark, and Gerard Whelan. 2011. "Twenty Years of Rail Crowding Valuation Studies: Evidence and Lessons from British Experience." Transport Reviews, 31(3): 379-398.

Whelan, G., and J. Crockett. 2009. "An Investigation of the Willingness to Pay to Reduce Rail Overcrowding." Proceedings of the First International Conference on Choice Modelling, Harrogate, England.

Zhan, Guangjun, Xuedong Yan, Shanjiang Zhu, and Yun Wang. 2016. "Using Hierarchical Tree-Based Regression Model to Examine University Student Travel Frequency and Mode Choice Patterns in China." Transport Policy, 45(C): 55-65.

\section{About the Authors}

JIANRONG LIU(212021@163.com) is a lecturer in the Department of Transportation Engineering, School of Civil Engineering and Transportation, South China University of Technology. His interests are in public transport services, stated preference modeling, and travel behavior.

HuIYING WeN (hywen@scut.edu.cn) is a professor in the Department of Transportation Engineering, School of Civil Engineering and Transportation, South China University of Technology. She leads several interdisciplinary research projects focusing on transport policy, transport planning, road safety, and public transportation. 
APPENDIX I: Summary of Reviewed Crowding Valuation Studies

\begin{tabular}{|c|c|c|c|c|c|c|}
\hline Author & Methods & Mode & $\begin{array}{c}\text { Way of Representing } \\
\text { Crowding }\end{array}$ & Measurement & Value & Classification \\
\hline Accent (2006) & $\begin{array}{l}\text { Discrete choice } \\
\text { model }\end{array}$ & Rail & $\begin{array}{l}\text { Qualitative } \\
\text { description }\end{array}$ & Multiplier & $\begin{array}{l}\text { When crowding varied from "seat } \\
\text { uncrowded" to "stand crowded," } \\
\text { multipliers increased from } 1 \text { to } \\
2.14 \text {. }\end{array}$ & None \\
\hline $\begin{array}{l}\text { Basu and } \\
\text { Hunt (2012) }\end{array}$ & $\begin{array}{l}\text { Discrete choice } \\
\text { model }\end{array}$ & Train & $\begin{array}{l}\text { Qualitative } \\
\text { description }\end{array}$ & Constant value & $\begin{array}{l}\text { Valuations of in-vehicle } \\
\text { were } 0.32,0.46,0.46,0.54 \text {, } \\
0.59 \text { Indian Rupees for light } \\
\text { crowding, moderate crowding, } \\
\text { heavy crowding, and very } \\
\text { heavy crowding, respectively, } \\
\text { adopting very light crowding as } \\
\text { benchmark. }\end{array}$ & None \\
\hline $\begin{array}{l}\text { Batarce et al. } \\
(2015)\end{array}$ & $\begin{array}{l}\text { Discrete choice } \\
\text { model }\end{array}$ & $\begin{array}{l}\text { Bus, } \\
\text { train }\end{array}$ & $\begin{array}{l}\text { Qualitative } \\
\text { description }\end{array}$ & Multiplier & $\begin{array}{l}\text { Value of in-vehicle travel time } \\
\text { varied from } \$ 4.60 \text { to } \$ 10.40 \text { when } \\
\text { standee density varied from } 1-2 \\
\text { standees } / \mathrm{m}^{2} \text { to } 5-6 \text { standees } / \mathrm{m}^{2} \text {. }\end{array}$ & None \\
\hline $\begin{array}{l}\text { Cantwell et al. } \\
(2009)\end{array}$ & $\begin{array}{l}\text { Discrete choice } \\
\text { model, linear } \\
\text { regression }\end{array}$ & $\begin{array}{l}\text { Train, } \\
\text { bus }\end{array}$ & $\begin{array}{l}\text { Qualitative } \\
\text { description }\end{array}$ & Constant value & $\begin{array}{l}\text { Ratio between valuation of train } \\
\text { crowding and bus crowding is } 1.4 \text {. }\end{array}$ & Train, Bus \\
\hline $\begin{array}{l}\text { Douglas and } \\
\text { Karpouzis } \\
(2006)\end{array}$ & $\begin{array}{l}\text { Discrete choice } \\
\text { model }\end{array}$ & train & $\begin{array}{l}\text { Combinations of } \\
\text { seating time, standing } \\
\text { time, degree of } \\
\text { crowdedness on train }\end{array}$ & Multiplier & $\begin{array}{l}\text { When crowding on train varied } \\
\text { from "crowded seat" to "crush } \\
\text { stand } 20 \text { minutes or longer," time } \\
\text { multiplier varied from } 1.17 \text { to } \\
2.52 \text {. }\end{array}$ & $\begin{array}{l}\text { Gender, Age, } \\
\text { Trip Purpose }\end{array}$ \\
\hline $\begin{array}{l}\text { Faber and } \\
\text { MacDonald } \\
\text { (2007) }\end{array}$ & $\begin{array}{l}\text { Discrete choice } \\
\text { model }\end{array}$ & Rail & $\begin{array}{l}\text { Qualitative } \\
\text { description }\end{array}$ & Multiplier & $\begin{array}{l}\text { When in-vehicle crowding } \\
\text { varied from "plenty of seats" to } \\
\text { "standees packed," multipliers } \\
\text { increased from } 1 \text { to } 3.01 \text { for } \\
\text { commuters, } 2.73 \text { for commuters. }\end{array}$ & $\begin{array}{l}\text { Commuter } \\
\text { or Not, Car } \\
\text { Availability, } \\
\text { Over } 40 \text { Min or } \\
\text { Not }\end{array}$ \\
\hline $\begin{array}{l}\text { Haywood and } \\
\text { Koning (2011) }\end{array}$ & $\begin{array}{l}\text { Ordered logit } \\
\text { Model }\end{array}$ & Subway & $\begin{array}{l}\text { Additional minutes } \\
\text { Willingness to wait } \\
\text { for more comfortable } \\
\text { subway }\end{array}$ & Constant value & $\begin{array}{l}\text { Travelers in Paris willing to } \\
\text { increase trip durations by } 5.7-8.1 \\
\text { minutes to enjoy off-peaks } \\
\text { comfort conditions during rush } \\
\text { hours. }\end{array}$ & $\begin{array}{l}\text { Age, } \\
\text { Socioeconomic } \\
\text { Status }\end{array}$ \\
\hline $\begin{array}{l}\text { Haywood and } \\
\text { Koning (2013) }\end{array}$ & $\begin{array}{l}\text { Discrete choice } \\
\text { model }\end{array}$ & Metro & Standee density & Multiplier & $\begin{array}{l}\text { Multiplier ranged from } 1.00 \text { to } \\
1.57 \text { when standee density ranged } \\
\text { from } 0 \text { to } 6 \text { pass } / \mathrm{m}^{2} \text {. }\end{array}$ & None \\
\hline $\begin{array}{l}\text { Hensher et al. } \\
\text { (2011) }\end{array}$ & $\begin{array}{l}\text { Discrete choice } \\
\text { model }\end{array}$ & $\begin{array}{l}\text { Metro, } \\
\text { bus }\end{array}$ & $\begin{array}{l}\text { Seats occupied, } \\
\text { number of standees }\end{array}$ & Multiplier & $\begin{array}{l}\text { With rise of number of standees, } \\
\text { crowding utility increased with a } \\
\text { quadratic function. }\end{array}$ & None \\
\hline $\begin{array}{l}\text { Kroes et al. } \\
(2013)\end{array}$ & $\begin{array}{l}\text { Discrete choice } \\
\text { model }\end{array}$ & $\begin{array}{l}\text { Metro, } \\
\text { bus, } \\
\text { train }\end{array}$ & Load factor & Multiplier & $\begin{array}{l}\text { When load factor were } 25-250 \% \text {, } \\
\text { multipliers were } 1-1.363 \\
\text { for seated train passengers, } \\
1.261-1.553 \text { for standing train } \\
\text { passengers, } 1-1.511 \text { for seated } \\
\text { bus passengers, } 1.342-1.718 \text { for } \\
\text { standing passengers. }\end{array}$ & None \\
\hline
\end{tabular}


APPENDIX I (cont'd): Summary of Reviewed Crowding Valuation Studies

\begin{tabular}{|c|c|c|c|c|c|c|}
\hline Author & Methods & Mode & $\begin{array}{l}\text { Way of Representing } \\
\text { Crowding }\end{array}$ & Measurement & Value & Classification \\
\hline Lu et al. (2008) & $\begin{array}{l}\text { Discrete choice } \\
\text { model }\end{array}$ & $\begin{array}{l}\text { Rolling } \\
\text { stock }\end{array}$ & $\begin{array}{l}\text { Combinations } \\
\text { of probability of } \\
\text { standing and length } \\
\text { of time }\end{array}$ & Multiplier & $\begin{array}{l}\text { Value of crowding estimated at } \\
12.05 \text { pence per person minute, } \\
\text { more than twice value of in- } \\
\text { vehicle time. }\end{array}$ & $\begin{array}{l}\text { Complex } \\
\text { Design, Cheap } \\
\text { Talk }\end{array}$ \\
\hline $\begin{array}{l}\text { MVA } \\
\text { Consultancy } \\
(2008)\end{array}$ & $\begin{array}{l}\text { Discrete choice } \\
\text { model }\end{array}$ & Rail & Standee density & Multiplier & $\begin{array}{l}\text { When standees density varied } \\
\text { from } 0-6 \text { pass } / \mathrm{m}^{2}, 1-1.81 \\
\text { (business, seating), } 1.91-2.16 \\
\text { (business, standing), 1-1.62 } \\
\text { (non-business, seating), 1-2.06 } \\
\text { (non-business, standing). }\end{array}$ & $\begin{array}{l}\text { Business, Non- } \\
\text { Business, Sit, } \\
\text { Stand, Regional, } \\
\text { Interurban }\end{array}$ \\
\hline $\begin{array}{l}\text { Prud'homme } \\
\text { et al. (2012) }\end{array}$ & Linear regression & Subway & Standee density & Constant & $\begin{array}{l}\text { WTP }(€ / \text { trip }) \text { equals to standee } \\
\text { density } \times 0.68 \text {. }\end{array}$ & None \\
\hline $\begin{array}{l}\text { Tirachini et al. } \\
(2013)\end{array}$ & $\begin{array}{l}\text { Discrete choice } \\
\text { model }\end{array}$ & Metro & $\begin{array}{l}\text { Load factor, standee } \\
\text { density }\end{array}$ & Multiplier & $\begin{array}{l}\text { Linear relationship between } \\
\text { multipliers and standee density. }\end{array}$ & None \\
\hline $\begin{array}{l}\text { Vovsha et al. } \\
\text { (2014) }\end{array}$ & $\begin{array}{l}\text { Discrete choice } \\
\text { model }\end{array}$ & $\begin{array}{l}\text { Bus, } \\
\text { LRT, } \\
\text { rail }\end{array}$ & $\begin{array}{l}\text { Qualitative } \\
\text { descriptions }\end{array}$ & Multiplier & $\begin{array}{l}\text { Non-linear relationship between } \\
\text { multipliers and standees density. }\end{array}$ & $\begin{array}{l}\text { Trip Purpose, } \\
\text { Age, Travel } \\
\text { Mode, Income, } \\
\text { Trip Length } \\
\end{array}$ \\
\hline $\begin{array}{l}\text { Wang and } \\
\text { Legaspi (2012) }\end{array}$ & $\begin{array}{l}\text { Discrete choice } \\
\text { model }\end{array}$ & Train & Load factor & Multiplier & $\begin{array}{l}\text { Multiplier was function of load } \\
\text { factor and standing time. }\end{array}$ & None \\
\hline $\begin{array}{l}\text { Whelan and } \\
\text { Crockett } \\
\text { (2009) }\end{array}$ & $\begin{array}{l}\text { Discrete choice } \\
\text { model }\end{array}$ & Train & $\begin{array}{l}\text { Load factor, standee } \\
\text { density }\end{array}$ & Multiplier & $\begin{array}{l}\text { When standee densities increases } \\
\text { from } 0 \text { to } 6 \text { pass } / \mathrm{m}^{2} \text {, time } \\
\text { multipliers of seated passengers } \\
\text { and standees increase from } 1 \text { to } \\
1.63 \text { and } 1.53 \text { to } 2.04 \text {, respectively. }\end{array}$ & $\begin{array}{l}\text { Trip Purpose, } \\
\text { Trip Length, } \\
\text { Income }\end{array}$ \\
\hline
\end{tabular}


APPENDIX II. Survey for Bus and Metro

\begin{tabular}{|c|c|c|c|c|c|}
\hline $\begin{array}{c}\text { Choice } \\
\text { Set }\end{array}$ & $\begin{array}{c}\text { Choice } \\
\text { ID }\end{array}$ & $\begin{array}{l}\text { Journey } \\
\text { Time }\end{array}$ & In-vehicle Crowding & Fare & $\begin{array}{c}\text { Waiting } \\
\text { Time }\end{array}$ \\
\hline \multirow{3}{*}{1} & 1 & $40 \mathrm{~min}$ & Some restrictions in movement, high probability of physical contact & $¥ 5$ & $10 \mathrm{~min}$ \\
\hline & 2 & $60 \mathrm{~min}$ & No seat, but can circulate freely & $¥ 3$ & $5 \mathrm{~min}$ \\
\hline & 3 & $45 \mathrm{~min}$ & No person standing inside car & $¥ 4$ & $15 \mathrm{~min}$ \\
\hline \multirow{3}{*}{2} & 1 & $40 \mathrm{~min}$ & No person standing inside car & $¥ 4$ & $15 \mathrm{~min}$ \\
\hline & 2 & $30 \mathrm{~min}$ & No seat, but can circulate freely & $¥ 3$ & $10 \mathrm{~min}$ \\
\hline & 3 & $45 \mathrm{~min}$ & Impossible movement, difficult to get on/off metro car & $¥ 5$ & $5 \mathrm{~min}$ \\
\hline \multirow{3}{*}{3} & 1 & $40 \mathrm{~min}$ & Impossible movement, difficult to get on/off metro car & $¥ 4$ & $10 \mathrm{~min}$ \\
\hline & 2 & $45 \min$ & No person standing inside car & $¥ 5$ & $15 \mathrm{~min}$ \\
\hline & 3 & $30 \mathrm{~min}$ & Some restrictions in movement, high probability of physical contact & $¥ 3$ & $5 \mathrm{~min}$ \\
\hline \multirow{3}{*}{4} & 1 & $45 \min$ & Some restrictions in movement, high probability of physical contact & $¥ 4$ & $5 \min$ \\
\hline & 2 & $40 \mathrm{~min}$ & No seat, but can circulate freely & $¥ 5$ & $15 \mathrm{~min}$ \\
\hline & 3 & $30 \mathrm{~min}$ & Impossible movement, difficult to get on/off metro car & $¥ 3$ & $10 \mathrm{~min}$ \\
\hline \multirow{3}{*}{5} & 1 & $45 \mathrm{~min}$ & Impossible movement, difficult to get on/off metro car & $¥ 4$ & $10 \mathrm{~min}$ \\
\hline & 2 & $60 \mathrm{~min}$ & No person standing inside car & $¥ 5$ & $5 \mathrm{~min}$ \\
\hline & 3 & $40 \min$ & Some restrictions in movement, high probability of physical contact & $¥ 3$ & $15 \mathrm{~min}$ \\
\hline \multirow{3}{*}{6} & 1 & $45 \mathrm{~min}$ & Some restrictions in movement, high probability of physical contact & $¥ 5$ & $10 \mathrm{~min}$ \\
\hline & 2 & $60 \mathrm{~min}$ & No person standing inside car & $¥ 3$ & $5 \mathrm{~min}$ \\
\hline & 3 & $60 \mathrm{~min}$ & No seat, but can circulate freely & $¥ 4$ & $5 \mathrm{~min}$ \\
\hline \multirow{3}{*}{7} & 1 & $30 \mathrm{~min}$ & Some restrictions in movement, high probability of physical contact & $¥ 4$ & $15 \mathrm{~min}$ \\
\hline & 2 & $45 \mathrm{~min}$ & No seat, but can circulate freely & $¥ 3$ & $10 \mathrm{~min}$ \\
\hline & 3 & $60 \mathrm{~min}$ & Impossible movement, difficult to get on/off metro car & $¥ 5$ & $10 \mathrm{~min}$ \\
\hline \multirow{3}{*}{8} & 1 & $30 \mathrm{~min}$ & No seat, but can circulate freely & $¥ 4$ & $5 \mathrm{~min}$ \\
\hline & 2 & $40 \mathrm{~min}$ & No person standing inside car & $¥ 3$ & $10 \mathrm{~min}$ \\
\hline & 3 & $45 \mathrm{~min}$ & Some restrictions in movement, high probability of physical contact & $¥ 5$ & $15 \min$ \\
\hline \multirow{3}{*}{9} & 1 & $60 \mathrm{~min}$ & Impossible movement, difficult to get on/off metro car & $¥ 3$ & $5 \mathrm{~min}$ \\
\hline & 2 & $30 \mathrm{~min}$ & No seat, but can circulate freely & $¥ 5$ & $15 \min$ \\
\hline & 3 & $40 \mathrm{~min}$ & Some restrictions in movement, high probability of physical contact & $¥ 4$ & $10 \mathrm{~min}$ \\
\hline \multirow{3}{*}{10} & 1 & $45 \min$ & Some restrictions in movement, high probability of physical contact & $¥ 5$ & $5 \mathrm{~min}$ \\
\hline & 2 & $40 \mathrm{~min}$ & No seat, but can circulate freely & $¥ 3$ & $10 \mathrm{~min}$ \\
\hline & 3 & $30 \mathrm{~min}$ & Impossible movement, difficult to get on/off metro car & $¥ 4$ & $15 \mathrm{~min}$ \\
\hline \multirow{3}{*}{11} & 1 & $45 \min$ & No seat, but can circulate freely & $¥ 4$ & $15 \mathrm{~min}$ \\
\hline & 2 & $40 \mathrm{~min}$ & No person standing inside car & $¥ 5$ & $5 \mathrm{~min}$ \\
\hline & 3 & $30 \mathrm{~min}$ & Some restrictions in movement, high probability of physical contact & $¥ 3$ & $10 \mathrm{~min}$ \\
\hline \multirow{3}{*}{12} & 1 & $45 \mathrm{~min}$ & No person standing inside car & $¥ 3$ & $10 \mathrm{~min}$ \\
\hline & 2 & $40 \mathrm{~min}$ & No seat, but can circulate freely & $¥ 4$ & $5 \mathrm{~min}$ \\
\hline & 3 & $30 \mathrm{~min}$ & Impossible movement, difficult to get on/off metro car & $¥ 5$ & $15 \mathrm{~min}$ \\
\hline
\end{tabular}


APPENDIX II (cont'd). Survey for Bus and Metro

\begin{tabular}{|c|c|c|c|c|c|}
\hline $\begin{array}{l}\text { Choice } \\
\text { Set }\end{array}$ & $\begin{array}{l}\text { Choice } \\
\text { ID }\end{array}$ & $\begin{array}{c}\text { Journey } \\
\text { Time }\end{array}$ & In-vehicle Crowding & Fare & $\begin{array}{c}\text { Waiting } \\
\text { Time }\end{array}$ \\
\hline \multirow{3}{*}{13} & 1 & $45 \mathrm{~min}$ & No seat, but can circulate freely & $¥ 3$ & $15 \mathrm{~min}$ \\
\hline & 2 & $60 \mathrm{~min}$ & Some restrictions in movement, high probability of physical contact & $¥ 4$ & $5 \mathrm{~min}$ \\
\hline & 3 & $60 \mathrm{~min}$ & No person standing inside car & $¥ 5$ & $10 \mathrm{~min}$ \\
\hline \multirow{3}{*}{14} & 1 & $45 \mathrm{~min}$ & Some restrictions in movement, high probability of physical contact & $¥ 3$ & $15 \mathrm{~min}$ \\
\hline & 2 & $40 \mathrm{~min}$ & No seat, but can circulate freely & $¥ 5$ & $10 \mathrm{~min}$ \\
\hline & 3 & $60 \mathrm{~min}$ & No person standing inside car & $¥ 4$ & $10 \mathrm{~min}$ \\
\hline \multirow{3}{*}{15} & 1 & $30 \mathrm{~min}$ & No person standing inside car & $¥ 4$ & $10 \min$ \\
\hline & 2 & $40 \mathrm{~min}$ & Impossible movement, difficult to get on/off metro car & $¥ 3$ & $15 \mathrm{~min}$ \\
\hline & 3 & $45 \mathrm{~min}$ & Some restrictions in movement, high probability of physical contact & $¥ 3$ & $5 \mathrm{~min}$ \\
\hline \multirow{3}{*}{16} & 1 & $45 \mathrm{~min}$ & No seat, but can circulate freely & $¥ 4$ & $10 \mathrm{~min}$ \\
\hline & 2 & $30 \mathrm{~min}$ & Some restrictions in movement, high probability of physical contact & $¥ 5$ & $10 \mathrm{~min}$ \\
\hline & 3 & $40 \mathrm{~min}$ & Impossible movement, difficult to get on/off metro car & $¥ 3$ & $5 \mathrm{~min}$ \\
\hline
\end{tabular}

